\title{
MONITORING OF MICROELEMENT COMPOSITION OF DRINKING WATER IN DIFFERENT REGIONS OF UKRAINE FOR 2019-2020
}

\author{
Svitlana Shuliak ${ }^{1}$ \\ Kateryna Miahka ${ }^{2}$
}

DOI: https://doi.org/10.30525/978-9934-26-050-6-7

Globalization in the world, particularly in Ukraine, creates the preconditions for the widespread use of industrial, agricultural and household waste, which directly or indirectly affects the quality and trace elements of water.

Deteriorating environmental conditions and unethical human interference with the natural system have strengthened concerns about improving healthy lifestyles. Deterioration of the water system is common in developing countries [1].

According to WHO, 80\% of human diseases are associated with the use of poor quality water. In accordance with international drinking water quality standards, Council Directive 98/83 EC [2] and the national standard of Ukraine DSTU 7525: 2014 [3], a clear list of chemical and toxicological groups of drinking water quality indicators is defined. The problem of drinking water pollution in Ukraine is related to the imperfection of wastewater treatment systems from industrial, municipal and agricultural enterprises, erosion of soils, as well as anthropogenic disasters that have severe and long-term consequences, in particular at the Chernobyl NPP [4].

\footnotetext{
${ }^{1}$ State Research Institute of Laboratory Diagnostics and Veterinary and Sanitary Expertise, Ukraine

${ }^{2}$ State Research Institute of Laboratory Diagnostics and Veterinary and Sanitary Expertise, Ukraine
} 
We establish the following goals: to analyse chemical and toxicological indicators of drinking water taken from different regions of Ukraine; to determine the quantitative content of aluminium, arsenic, boron, cadmium, mercury, chromium, cobalt, copper, iron, plumbum, manganese, molybdenum, selenium, nickel, sodium and zinc in water samples.

The research was carried out on the basis of the State Research Institute of Laboratory Diagnostics and Veterinary and Sanitary Expertise, Laboratory of Atomic Absorption Spectrometry by the method of inductively coupled plasma atomic emission spectroscopy (ICP-AES) (optical emission spectrometer PlasmaQuant PQ 9000 Analytik Jiena (Germany)) and atomic absorption spectrometry [5; 6]. Water samples were taken according to DSTU ISO 5667-3-2001 [7].

In the period from 2019 to 2020, tests of 227 water samples were conducted, of which 11 gave positive results (4.84\%), in terms of ferrum content -8 samples, in terms of manganese -3 samples (Table 1 ).

Table 1

Analysis of chemical and toxicological parameters of drinking water, $\mu \mathrm{g} / \mathrm{L}$

\begin{tabular}{|c|c|c|c|}
\hline \multirow{2}{*}{ Indicator } & Concentration & \multicolumn{2}{|c|}{ Reference document } \\
\cline { 3 - 4 } & range & $\begin{array}{c}\text { State Standard } \\
\text { of Ukraine } \\
\mathbf{7 5 2 5 : 2 0 1 4}\end{array}$ & $\begin{array}{c}\text { Council } \\
\text { Directive } \\
\mathbf{9 8 / 8 3 / E C}\end{array}$ \\
\hline Plumbum & $1.103-5.102$ & 10 & 10 \\
\hline Cadmium & $2.0-5.0$ & 1 & 5 \\
\hline Arsenic & $1.626-3.325$ & 10 & 10 \\
\hline Mercury & $0.127-1.047$ & 0.5 & 1 \\
\hline Antimony & $0.524-2.194$ & 5 & 5 \\
\hline Nickel & $3.587-6.380$ & 20 & 20 \\
\hline Chromium & $2.662-10.395$ & 50 & 50 \\
\hline Aluminium & $10.297-50.025$ & 200 & 200 \\
\hline Copper & $0.026-0.058$ & 1000 & 200 \\
\hline Iron & $84.277-570.458$ & 200 & 50 \\
\hline Manganese & $8.741-130.295$ & 50 & 1000 \\
\hline Boron & $0.117-0.394$ & 500 & 10 \\
\hline Selenium & $3.529-7.842$ & 10 & 200000 \\
\hline Sodium & $45.034-109.036$ & 200 & \\
\hline
\end{tabular}

The results of water tests showed that the quantitative content of plumbum, arsenic and cadmium in the samples was in the range of $1.103-5.102 \mu \mathrm{g} / \mathrm{kg}$, which was within the normative values. 
The variability of the quantitative content of chromium, cobalt, nickel and molybdenum depended on the region of the selected samples and did not exceed the maximum allowable levels.

Arsenic and mercury in all water samples were detected in minimum concentrations - trace amounts, or below the method detection limit of $0.5 \mu \mathrm{g} / \mathrm{kg}$.

The quantitative content of iron in almost all water samples was at the limit of the maximum allowable concentration (MAC) and exceeded it in 8 samples (Kyiv oblast - in 2.1 times, Chernihiv oblast - in 3.1 times, Odesa oblast - in 2 times, Dnipropetrovsk oblast - in 1.2 times). The origin of iron in water can be of geogenic nature or from industrial effluents, household waste, as well as due to significant wear of the water supply system.

Pollution of drinking water with copper, boron and selenium was not detected among the regions of Ukraine. Aluminum, sodium, and zinc did not exceed the normative values. The content of sodium in water was characterized by significant variability, which is due to the peculiarities of the entry of its compounds with industrial and municipal effluents into the water, but the excess of the maximum allowable concentrations was not detected. The concentration ranges of aluminum, sodium and zinc in the water of the oblasts of Ukraine in all cases were below MACs according to the standards of both national and European legislation.

Manganese was detected in excess of MACs in three samples, accordingly, $85.62 \mu \mathrm{g} / \mathrm{kg} ; 98.88 \mu \mathrm{g} / \mathrm{kg}$ and $130.29 \mu \mathrm{g} / \mathrm{kg}$. The main sources of manganese contamination of drinking water in Ukraine are considered to be untreated wastewater from industrial metallurgical enterprises, municipal wastewater and low efficient outdated wastewater treatment systems.

It is established that $95.15 \%$ of drinking water samples that were tested and selected in different regions of Ukraine for the content of chemical elements met the requirements of current regulations. Exceedance of MACs for iron and manganese was in $4.84 \%$ of samples. The content for such toxic elements as $\mathrm{As}, \mathrm{Cr}, \mathrm{Pb}, \mathrm{Cd}, \mathrm{Ni}$ in the drinking water of the regions of Ukraine from which samples were tested was within the normative values. However, despite this fact, they pose a potential risk to consumer health even in low doses.

Therefore, the application of measures based on constant control (monitoring) of drinking water quality is important for public health.

\section{References:}

1. Khan T. (2011) Trace Elements in the Drinking Water and Their Possible Health Effects in Aligarh City, India. Journal of Water Resource and Protection, 3(7): 522-530. doi: 10.4236/jwarp.2011.37062 
2. Council Directive 98/83/EC of 3 November 1998 on the quality of water intended for human consumption OJ L 330, 5.12.1998, p. 32-54. URL: https://eur-lex.europa.eu/legal-content/EN/TXT/?uri=celex\%3A31998L0083

3. DSTU 7525-2014 Voda pytna. Vymohy ta metody kontroliuvannia yakosti. [Drinking water. Quality control requirements and methods. Kyiv: State Consumer Standard]. Kyiv: Derzhspozhyvstandart, 2014. 25 p. (in Ukrainian)

4. Opalov O.A. (2000) Ekoloho-ekonomichna otsinka vodnykh resursiv Ukrainyiu Formuvannia rynkovykh vidnosyn $\mathrm{v}$ Ukraini, 9: 84-89 [Ecological and economic assessment of water resources of Ukraine Formation of market relations in Ukraine, 9: 84-89]. (in Ukrainian)

5. ISO 11885:2007 Water quality - Determination of selected elements by inductively coupled plasma optical emission spectrometry (ICP-OES). Second edition 2007-08, 13.060.50, $28 \mathrm{p}$.

6. ISO 12846:2012 Water quality - determination of mercury - method using atomic absorption spectrometry (AAS) with and without enrichment. First editions 2012-04-15, Case postale 56 CH-1211 Geneva 20, 15 p.

7. ISO 5667-3:2003 Water quality - Sampling - Part 3: Guidance on the preservation and handling of water samples. Third edition 2003-12, 13.060.45, $31 \mathrm{p}$. 